\title{
Mesiodistal Gradient of Mandibular Precedence in the Developing Dentition
}

\author{
ALPHONSE R. BURDI, STANLEY M. GARN, and RICHARD L. MILLER
}

Department of Anatomy and Center for Human Growth and Development, University of Michigan, Ann Arbor, Michigan 48104

In postnatal dental development, there are clear-cut mandibular-maxillary eruption precedences; usually the mandibular incisors tend to precede their maxillary opponents. There is also a mesiodistal gradient of mandibularmaxillary precedence such that maxillary precedence becomes both relatively and absolutely more common in the posterior teeth ( $H$. IsRaEL, A. Dahlberg, S. M. GARN, and R. KEREWSKY, J Dent Res 46:456, 1967; and H. IsRAEL, S. M. GARN, and R. F. BENITEZ, Arch Oral Biol 13:239-241, 1968). It is not known, however, whether such precedent polymorphisms exist in prenatal dental development and whether they have their origins in the first trimester of existence.

To test this possibility, the relative development of maxillary and mandibular deciduous opponents in a series of 52 human embryos, all below $58 \mathrm{~mm}$ in crown-rump length, was examined. The developmental status of each tooth was assessed individually and described by a numerical code; the results were incorporated on standard IBM 80 -column punch cards. Then for each pair of opponents, dental development was categorized as (1) mandible

Supported in part by USPHS Grant HD-02272 from the National Institute of Dental Research, National In stitutes of Health, Bethesda, Md, and the University of Michigan Faculty Research Grant Project 21.

Additional information available on request to authors.

Received for publication November 17, 1969. ahead, (2) equal development, or (3) maxilla ahead, depending on the precoded assessments obtained from the IBM 360-67 computer calculations.

Deciduous opponents usually are of comparable development, but there are also clearcut formation precedences during early fetal life (Table). For the eight deciduous incisors, mandibular precedence is far more common $(25 \%)$ than maxillary precedence $(5 \%)$. However, for the eight deciduous molars, mandibular and maxillary precedences are equally common (approximately $10 \%$ for each). Furthermore, there is a clear-cut mesiodistal gradient characterized by a shift in relative proportions of mandibular precedence in the incisors to maxillary precedence in the deciduous molars. The departure from simple chance distribution of mandibular and maxillary precedences is highly significant for the deciduous incisors and the canines (using the chi-squared test), as is the difference in distribution of precedences between deciduous incisors as a group and deciduous molars as a group.

Although it cannot be assumed that 8- to 12 week embryos with maxillary or mandibular incisor precedence would exhibit the same sequences in later deciduous or permanent tooth eruption, it is clear that the mandibular-maxillary precedent polymorphisms and the gradients that exist in postnatal dental emergence have close parallels in very early tooth-formation timing.

Mesiodistal Gradient of Mandibular Precedence in Developing Dentition

\begin{tabular}{lccccc}
\hline Tooth & $\begin{array}{c}\text { No. of } \\
\text { Sides }\end{array}$ & $\begin{array}{c}\text { Mandible } \\
\text { Ahead }\end{array}$ & $\begin{array}{c}\text { Maxilla } \\
\text { Ahead }\end{array}$ & $\begin{array}{c}\text { Equal De- } \\
\text { velopment }\end{array}$ & $\chi^{2}$ \\
\hline $\mathrm{I} 1$ & 104 & 23 & 2 & 79 & $16.0^{*}$ \\
$\frac{\mathrm{I} 2}{\mathrm{I} 2}$ & 104 & 27 & 7 & 70 & 11.8 \\
$\frac{\mathrm{C}}{\mathrm{C}}$ & 104 & 17 & 8 & 79 & 3.2 \\
$\frac{\mathrm{dm} 1}{\mathrm{dm} 1}$ & 104 & 13 & 8 & 83 & 1.2 \\
$\frac{\mathrm{dm} 2}{\mathrm{dm} 2}$ & 104 & 9 & 12 & 83 & 0.4 \\
\hline$* 2 \times 2$ & $\times 2$, against chance or $50: 50$ hypothesis, using Yates' correction.
\end{tabular}

